Podplukovník Ing. Pavel Otřísal, Ph.D., MBA

Některé aspekty vnímání pojmu

dekontaminace na národní

\title{
Some Aspects of Term of Decontamination Perception on Both National and Alliance Levels
}

\section{Abstrakt:}

Vymezení termínu „dekontaminace“ vychází jednak z aliančních norem, národních vojenských předpisů a publikací, ale také z dokumentů, které se zabývají pojetím dekontaminace pro civilní účely, tedy dokumenty Hasičského záchranného sboru České republiky. Studiem aliančních a národních dokumentů bylo zjištěno, že v mnohých př́padech je tento pojem uváděn rozdílně, což může zpusobit nejednoznačný výklad a chápání plněných dekontaminačních opatření, a tedy $i$ celkovou nejednotnost $v$ rámci nejenom Aliance, ale $i$ vybraných základních a ostatních složek integrovaného záchranného systému České republiky. Článek analyzuje př́stupy k pojmu „,dekontaminace“ s tím, že jej specifikuje téměr výhradně na základě uváděných definic. Na konci článku jsou uvedena doporučení, kterými by se management chemického vojska Armády České republiky měl v předmětné oblasti zabývat.

\section{Abstract:}

The classification of a term of "decontamination" comes out not only from the Alliance norms, national military regulations and publications, but also from the documents that deal with the conception of decontamination for civilian purposes, i.e. from documents of the Fire Rescue Brigades of the Czech Republic. The study of both Alliance and national documents has proved that in many cases this term is being introduced in a different way which might cause not very homogenous interpretation and understanding to accomplished decontamination measurements and thus even overall disunity in a framework not only of Alliance, but also in selected basic and other parts of the Integrated Rescue System of the Czech Republic. The paper analyses approaches to the term of "decontamination"practically only by means of definitions in use nowadays. At the end of this document there are recommendations which ought be considered by the management of the Czech Armed Forces Chemical Corps within the area of its respective interest.

\section{Klíčová slova:}

Dekontaminace, AAP-6, NN 30 0101, vojenský předpis, chemické vojsko, Armáda České republiky.

Key words:

Decontamination, AAP-6, NN 30 0101, military regulation, Chemical Corps, Czech Armed Forces. 
Motto:

Ne ze souhlasu, ale z pochybnosti rodí se pokrok. [1]

\section{Úvod}

Teoretická i praktická připravenost specialistů chemického vojska (CHV) Armády České republiky je základním předpokladem pro plnění odborných úkolů spadajících do rámce chemického zabezpečení (CHZ) [2] a ochrany proti zbraním hromadného ničení (ZHN). [3] Jednou z nezbytných součástí teoretického základu př́pravy specialistů CHV AČR je nepochybně znalost terminologie a příslušného pojmového aparátu, který je v současné době značně nejednotný a mnohdy prakticky nepochopitelný. Právě správné pochopení, následný výklad a vlastní aplikace odborné terminologie, vytváří předpoklady pro přesně formulované vlastní myšlenky založené na zcela jednoznačném popisu procesů doprovázejících konkrétní skupinu opatření naplňovaných opatření $\mathrm{CHZ}$ a ochrany proti ZHN, jejichž praktickou aplikaci velitel (náčelník) v boji či operaci očekává. V současné době je terminologický aparát poměrně nejednotný, což se projevuje zejména v oblasti realizace vzájemné součinnosti při plnění aliančních úkolů v rámci mnohonárodních vojenských uskupení. Navíc určitá nejednotnost chápání některých pojmů má dopad i do plnění úkolů při operacích v rámci integrovaného záchranného systému (IZS) ČR, ve kterých ozbrojené síly ČR a potažmo i CHV AČR sehrávají nezastupitelnou roli. V následujícím textu bude termín „,dekontaminace“ (decontamination) studován a detailně analyzován jednak z pohledu problematiky vojensko-operační, tak i z pohledu civilního chápání uvedeného termínu, tedy tak, jak jej chápou, případně jak by jej měli chápat vojenští specialisté CHV AČR při plnění úkolů všech typů vojenských operacích včetně operací v rámci IZS ČR, resp. ve prospěch Hasičského záchranného sboru (HZS) ČR.

\section{Problematika vojensko-operačního pojetí pojmu dekontaminace}

Vojenský předpis NN 300101 [4] je základním dokumentem, který se zabývá terminologií v gesci CHV AČR s určitou mírou přesahu do vševojskového chápání problematiky bojového a operačního použití CHV AČR. V tomto předpisu je pojem dekontaminace definován doslova takto: „Postup, při němž se odstraňují nebo zneškodňují bojové chemické a průmyslové chemické látky, biologické látky nebo odstraňují radioaktivní látky z povrchu těla osob, výzbroje, techniky, jiného materiálu, objektů a terénu. Tvoří součást chemického zabezpečení. Z operačního hlediska se dekontaminace dělí na okamžitou, částečnou a úplnou. Zvláštní případ úplné dekontaminace je čistá dekontaminace (clearance decontamination). Z hlediska použitých dekontaminačních látek a dekontaminačních postupů se dělí na dezaktivaci, dezinfekci a odmořování (detoxikaci). Z hlediska dekontaminačního postupu se skládá z hrubé očisty, vlastní dekontaminace dekontaminační směsí a zpravidla i následného oplachu nekontaminovanou vodou. Dříve používaný termín pro dekontaminaci je speciální očista.“(AAP-21). K této definici je možné uvést několik základních poznatků a námětů k zamyšlení:

- Odvolávka na spojeneckou administrativní publikaci AAP-21 [5] která sice byla k datu 31. 12. 2012 bez náhrady zrušena oznámením Registru obranné 
standardizace Úřadu pro obrannou standardizaci, katalogizaci a státní ověřování jakosti v měsíci únoru $2012[6,7]$ je umístěna v místě, kde neodpovídá konkrétnímu znění definice vyplývající z ní.

- Odvolávka na AAP-21 by měla být uvedena hned za textem první věty. Význam této úvahy je umocněn informací o dříve používaném pojmu „speciální očista“, který v Severoatlantické alianci nebyl nikdy zaveden, přirozeně ani jeho anglicky uváděným ekvivalentem nebo i takovým, který by mu byl podobný. Pro úplnost je nutné uvést, že vztah k již zrušené spojenecké publikaci AAP-21 je zcela zásadní, a proto je zde zmíněna i přesto, že již není platná. Podle věrohodných informací [8] má názvosloví uvedené v AAP-21 postupně přejde do spojenecké administrativní publikace AAP-6. [9] Tento proces byl sice již zahájen, ale z původního názvosloví uvedeného $\mathrm{v}$ AAP-21 je prozatím převedena pouze velmi malá část, a navíc se stejnými nedostatky, které se v AAP-21 objevily, a proto jsou $\mathrm{v}$ dalším textu uváděny.

- Text za první větou nebyl uveden ani v AAP-21 a není uveden dokonce ani v AAP-6 jak je patrné z následujícího textu. Význam slova definice, který je obecně chápán jako slovní zavedení a objasnění obsahu, významu pojmu nebo výrazu, mne vede $\mathrm{k}$ přesvědčení, že vysvětlení pojmu by mělo inklinovat $\mathrm{k}$ jednoznačnosti, a tedy $\mathrm{k}$ co největší stručnosti s použitím minimálního množství terminologického aparátu, který musí být dále dodatečně vysvětlován. Aplikací tohoto přistupu by se dosáhlo větší míry podobnosti zněním uvedeným v bývalé AAP-2,1 a zvláště v AAP-6. Zejména v AAP-6 je naplnění významu termínu definice jednoznačnější, protože na další odborné pojmy je poukázáno patřičným odkazem, což je z hlediska unikátního pochopení významu vyhovující.

- V první větě je uvedena spojka slučovací „a“ mezi slovy „objektư“a „,terén“, což neodpovídá znění uvedenému v AAP-21, resp. AAP-6, na který se tato definice odvolává. Ve znění, které bylo uvedeno v AAP-21, byla použita spojka vylučovací „or“, která posunuje zacílení úkolů souvisejících s prováděním dekontaminace do poněkud odlišné roviny.

- V textu definice je uvedeno, že: „Tvoří součást chemického zabezpečení.“ To je sice pravdivé tvrzení, ale bylo by přesnější, kdyby bylo uvedeno, že: „,... tvoří součást CHZ a ochrany proti ZHN.“"Toto tvrzení lze opřít o skutečnost, že součástí opatření ochrany proti ZHN jsou úkoly zahrnující odstraňování následků použití ZHN, úniků průmyslových nebezpečných látek (PNL) a následků způsobených ničením zbraňových systémů, skladových a výrobních kapacit ZHN. Odstraňování následků zahrnuje využití zásad, pracovních postupů a materiálu k minimalizaci těchto následků včetně dekontaminace a zabránění vzniku nebo omezení šíření kontaminace. Do ostrého kontrastu k tomuto tvrzení se dostává definice dekontaminace uvedená v dnes již velmi zastaralém, ale doposud stále platném vojenském předpisu Vševojsk-2-11. [10] Předmětný pojem tento vojenský předpis specifikuje takto: „Speciální očista je jedním z opatření při odstraňování následků po použití zbraní hromadného ničení nepřítelem.“ Oprostíme-li se od výrazu „speciální očista“, zjistíme, že předpis nepracuje s pojmem „chemické zabezpečeni““ ačkoli byl $\mathrm{v}$ době jeho zpracování všeobecně užíván, a tedy zcela jednoznačně existoval. Zjednodušeně řečeno, doplněním definice uvedené v NN 300101 o toto dílčí ustanovení - které ve svém jádru je pro oblast ochrany proti ZHN výstižné, 
i přesto, že je napsáno v duchu doby, kdy ČR nebyla členem NATO - by došlo ke kvalitativnímu posunu její aplikace do celého spektra vojenských opatření, ve kterých jsou opatření dekontaminace prováděna.

- Č́st týkající se popisu dekontaminačního postupu se v tomto konkrétním vyjádření týká pouze dekontaminace bojové techniky. V této podobě jednoznačně není aplikovatelný pro dekontaminaci osob a už vůbec ne pro dekontaminace raněných osob. Za nejvíce diskutabilní považuji tvrzení, že v rámci dekontaminačního postupu je uvedeno „vlastní dekontaminace dekontaminační směsí“, a to $\mathrm{z}$ toho důvodu, že použití standardně zavedených dekontaminačních směsí pro zabezpečení dekontaminace povrchu osob by z hlediska jejich současného složení bylo velmi problematické. Navíc je prakticky nerealizovatelné, aby tzv. hrubá očista byla aplikována ve prospěch osob (i raněných) v současné době, kdy je standardně realizována řadou tří stanů vzájemně propojených do jednoho celku. Pro úplnost uvádím celé znění pojmu „hrubá očista“. Názvoslovnou normou NN 300101 je stanoveno, že hrubá očista je: „První dílčí operace v dekontaminačním postupu. Spočívá v odstranění velkých nečistot z kontaminované výzbroje (zpravidla vozidel) proudem tlakové vody nebo mechanicky.“

- Za poměrně diskutabilní je možné považovat i neúplný výčet kontaminantů, jejichž vliv je možné dekontaminací eliminovat. Doplněním o pojem „toxická látka“, kterou je chápána jakákoli sloučenina, která může svým působením na životní procesy způsobit smrt, dočasné zneschopnění nebo trvalou ujmu na zdraví lidí, živočichů nebo zničení či poškození rostlin, by se dosáhlo vy̌̌ší univerzálnosti uvedené definice.

Dalším národním zdrojem, odkud je čerpán terminologický aparát pro tvorbu dokumentů nejrůznějš́ího charakteru, je Vojenský výkladový slovník vybraných operačních pojmů. [11] V něm je uvedeno, že dekontaminace je: „Postup, př̌ němž se odstraňují nebo zneškodňují toxické chemické látky a bojové biologické látky nebo odstraňují radioaktivní látky z povrchu těla osob, výzbroje, jiného materiálu, objektů a terénu. Tvoří součást CHZ. Dekontaminace se dělí na: okamžitou, částečnou a úplnou (operačního hlediska), dezaktivaci, dezinfekci a detoxikaci/odmoření (podle použitých dekontaminačních látek a postupů) a hrubou očistu, vlastní dekontaminaci dekontaminační směsí a zpravidla i následný oplach nekontaminovanou vodou (podle použitých dekontaminačních látek a postupů)." Pominu-li gramatickou chybu v podobě nesprávně voleného pádu textu uvedeného v první závorce definice resp. chybějící předložky, tak tato definice pracuje s odlišným, poněkud širším způsobem pojatým terminologickým aparátem, který neodpovídá NN 300101 ve znění vydání z roku 2009.

Znění této definice prakticky úplně odpovídá názvoslovné normě NN 300101 z roku 2002, a to v textu prvních dvou vět. Na ostatní text této definice se dají přiměřeně aplikovat připomínky uvedené v předchozím textu. Za cenný lze uvést text v poslední závorce, který poněkud napravuje ustanovení o nutnosti provedení hrubé očisty i ve prospěch dekontaminace osob.

Výše zmíněná alianční (spojenecká) administrativní publikace AAP-21 definovala pojem dekontaminace takto: The process of making any person, object, or area 
safe by absorbing, destroying, neutralizing, making harmless, or removing chemical or biological agents, or by removing radioactive material clinging to or around it. (AAP-6) [9]

K této definici, která již byla částečně analyzována v textu výše, uvádím další dílčí náměty k zamyšlení:

- Ve znění definice se uvažuje pouze o procesech absorpce. Z hlediska záchytu radioaktivního materiálu by bylo nepochybně přesnější, aby byl použit i pojem popisující mechanismy adsorpce. V definičním pojetí by se pak jednalo o přesnější uvedení bud’ obou pojmů „absorbováním“ a „adsorbováním“ (absorbing and adsorption) nebo jednoduše jen ,sorpcí“ (sorption).

- V této definici je použita spojka ve spojení slov „object, or area“. Použití spojky typické pro vylučovací poměr může v praxi znamenat, že se popsané procesy týkají jednoho či druhého. Podle tohoto faktického znění by tedy nemělo být uvažováno s variantou týkající objektů a prostorů současně. Toto znění je ale v rozporu s definicí uvedenou v NN 300101.

- Uvedené znění definice se odvolává na znění AAP-6, což je částečně zavádějící. Ve znění textu definice vycházející ze zrušené AAP-21, která se odvolává na AAP-6, navíc obohaceného o odvolávku na související (příbuzné) pojmy, by se dalo čekat, že bude více odpovídat znění definice podle NN 30 0101. Předpokladem odborně zaměřeného názvosloví prezentovaného v AAP-21 mělo být zejména to, že vševojskové názvosloví obohatí o informace potřebné k detailnějšímu porozumění pojmu, které bude užitečné pro specialisty $\mathrm{CHV}$ napříč NATO, což se v tomto př́padě pouhým opisem nestalo. Námětem k zásadní polemice může být skutečnost, že není možno tak zvaně on-line vysledovat, zde předmětný pojem již byl či nebyl převeden z již neexistující AAP-21 do AAP-6. V každém prŕípadě tento př́stup k chápání těchto pojmů bylo možné ještě donedávna dohledat.

Definice pojmu decontamination je zahrnuta také dlouhodobě v alianční administrativní publikaci AAP-6, o které již bylo pojednáno výše. Ta tento termín definuje jako: The process of making any person, object, or area safe by absorbing, destroying, neutralizing, making harmless, or removing, chemical or biological agents, or by removing radioactive material clinging to or around it. Related terms: immediate decontamination, operational decontamination, thorough decontamination. [9]

S přihlédnutím k tomu, že AAP-6 není primárně určena pro specifikaci odborně zaměřeného názvosloví, tak i přesto se domnívám, že by i zde měl být zachován princip vyváženosti informací zejména v těch případech, kdy je na další pojmy př́ímo odkazováno. V závěrečné části definice je totiž odkazováno na související pojmy, mezi nimiž je i úplná dekontaminace (thorough decontamination). Dalším studiem tohoto pojmu ve stejné publikaci bylo zjištěno, že v ní nejsou zmíněny parciální procesy, kterými se dekontaminace dosahuje.

Za zásadní považuji absenci definice pojmu „čistá dekontaminace“ (clearance decontamination), která je podle současného chápání jejího významu součástí úplné dekontaminace. Uvedení tohoto pojmu považuji za závažné zejména z důvodu neexistence popisu konkrétních postupů, jejichž aplikací se dosáhne stavu, pro který se tento typ dekontaminace aplikuje. 
V listopadu loňského roku proběhla distribuce vojenské doktríny (publikace) označené Pub-36-16-02. [12] Jejím účelem je upřesnit základní principy ochrany proti ZHN, které jsou definovány doktrínou ochrany proti ZHN pro operační úroveň. [13] Celá tato oblast je v praxi řěsena ve třech dílech:

$\square$ 1. díl, který je obsahem publikace Pub-36-16-02, řeší obecná opatření ochrany proti ZHN v operacích, [14]

2. díl řeší odborné schopnosti v oblasti ochrany proti ZHN [15]

$\square$ 3. díl poskytuje podrobnější informace o oblasti vzdělávání, výcviku, plánování cvičení a vyhodnocování protokolů. [16]

Jak bylo uvedeno výše, publikace vychází ze standardizační dohody STANAG 2451. Tato dohoda definuje pojem decontamination jako: The process of making personnel, objects or areas safe by absorbing, destroying, neutralizing, making harmless, or removing chemical or biological agents and radioactive material.

Z porovnání tohoto znění se zněním uvedeným v AAP-6 je zřejmé, že i zde dochází k poněkud odlišnému pojetí. Není zde zmíněn proces zabezpečení „odlepení“ radioaktivních částic z kontaminovaných povrchů, což činí definici daleko univerzálnější a lépe pochopitelnější. V podstatě je ale možné konstatovat, že definice ve svém překladu odpovídá ustanovení standardizační dohody STANAG 2451. Za problematickou je možné považovat skutečnost, že stejnou definici pro dekontaminaci vojenská doktrína používá i pro aktivní dekontaminaci, což v zásadě pravdivé není. Názvoslovná norma NN 300101 totiž uvádí pojmy ,,aktivní dekontaminace“ a „pasivní dekontaminace“ zvlášt' a velmi jednoduše. Lze uvést, že se jedná o diametrálně odlišné procesy.

Pro doplnění přístupu k pojmu dekontaminace uvádím definici pojmu po jeho zadání do internetového vyhledavače google v anglické verzi. Jako první se zobrazí odkaz [17] na kterém je předmětný pojem definován takto:

Decontamination is the reduction or removal of chemical agents. Decontamination may be accomplished by removal of these agents by physical means or by chemical neutralization or detoxification. Decontamination of skin is the primary concern, but decontamination of eyes and wounds must also be done when necessary. Personal decontamination is decontamination of self, casualty decontamination refers to the decontamination of casualties, and personnel decontamination usually refers to decontamination of non-casualties.

Uvedená definice odkazuje na ,americkou federaci vědců“, a proto je s podivem, že v definici nejsou ani náznakem zmíněny otázky související s likvidací biologické ani radioaktivní kontaminace, tedy s dezinfekcí biologických látek (agens) a dezaktivací povrchů kontaminovaných radioaktivními látkami.

\section{Problematika pojetí pojmu dekontaminace v rámci HZS ČR}

V požární ochraně (PO) se problematika dekontaminace začala významněji řešit v období mezi léty 1992-1994, kdy byl zaznamenán trvalý nárůst zásahů jednotek PO na nebezpečné látky se zaměřením na dekontaminaci od průmyslových škodlivin a radioaktivních látek.

Kotinský a Hejdová [18] uvádějí, že: ,,V různých dostupných odborných materiálech jsou uváděny odlišné definice pro dekontaminaci, o kterých lze polemizovat.“ Ačkoli by 
se toto tvrzení mohlo stát mottem tohoto článku, tak je nutné uvést, že definici, kterou pro specifikaci pojmu dekontaminace používá, respektuje ustanovení uvedená v Řádu chemické služby [19] který je v rámci HZS považován za základní dokument zabývající se problematikou zásahů v kontaminovaných prostorech a přjímáním opatření k odstranění následků po zásazích v nich.

Podle tohoto dokumentu je dekontaminace definována jako: „Soubor metod, postupů, organizačního zabezpečení a prostředků k účinnému odstranění nebezpečné látky (kontaminantu). Vzhledem k tomu, že absolutní odstranění kontaminantu není možné (zůstává tzv. zbytková kontaminace), rozumí se dekontaminací snížení škodlivého účinku kontaminantu na takovou bezpečnou úroveň, která neohrožuje zdraví a život osob a zvířat, a jeho likvidace."

Tato definice velice obecně poukazuje na procesní přístup k realizaci dekontaminace. Slovní spojení „odstranění nebezpečné látky (kontaminantu)“ hodnotí dekontaminační procesy v podstatě pouze z pohledu dezaktivace. Dezaktivace je podle NN 300101 definována jako: „Odstraňování radioaktivních látek z povrchů osob, výzbroje, jiného materiálu, objektů a terénu. Je součástí dekontaminace. K dezaktivaci se používají dezaktivační směsi.“

I přesto, že pod pojmem kontaminant může být chápáno celé spektrum bojových chemických látek (BCHL), radioaktivních látek (RL), biologických agens, průmyslových nebezpečných látek (PNL) a dalších toxických látek, takto pojatá definice spíše inklinuje k aplikaci uvedeného souboru metod, postupů, organizačního zabezpečení a prostředků pouze ve vztahu k odstranění RL avšak bez rozlišení toho, zda vznikly jako produkty štěpné reakce po použití jaderných zbraní, případně jako radioaktivní materiál rozptýlený po použití radiologických zbraní typických pro použití jaderného materiálu teroristy, anebo jako radioaktivní materiály, které jsou souhrnně označovány jako průmyslové radioaktivní látky, tedy takové látky v pevném, kapalném, plynném nebo aerosolovém stavu, které se používají nebo skladují k průmyslovým, obchodním, zdravotnickým, vojenským nebo hospodářským účelům a mají škodlivý vliv na životní prostředí a živé organismy.

Užití pojmu ,zbytková kontaminace“ na druhou stranu uvozuje komplexní pohled na hodnocení výsledků dekontaminace ve všech variantách jejího provedení ve vztahu k použitým dekontaminačním látkám a postupům, a to z toho důvodu, že zbytková kontaminace je chápána jako kontaminace, kterou způsobují kontaminanty, které zůstanou v objektech po ukončení dekontaminace. Zbytková kontaminace se zpravidla vyjadřuje jako plošná aktivita jednotkového povrchu po jeho dezaktivaci (v případě RL), množství toxické látky na jednotkovou plochu po jejím odmoření (v případě BCHL apod.) nebo množství škodlivých mikroorganismů po dezinfekci (v případě bojových biologických prostředků a průmyslových biologických látek).

Za velmi pozitivní považuji chápání „civilního“ pohledu na dekontaminaci z hlediska likvidace kontaminantu. I přesto, že požadavek na likvidaci kontaminantů včetně tzv. procesních vod je trvale vznášen i při plnění úkolů v rámci dekontaminace vojsk, tak požadavek na likvidaci těchto vysoce nebezpečných odpadů zmíněn v ryze vojenských definicích není. Z tohoto pohledu se tato definice stává univerzálnější i přesto, že řešení problematiky procesních vod je v civilním prostředí požadavkem daleko pochopitelnějším než při plnění úkolů dekontaminace ve vojenských operacích. 


\section{Závěr}

Po provedení analýzy pojmu dekontaminace resp. jeho anglického ekvivalentu decontamination je zřejmé, že přesné vymezení tohoto jediného pojmu, a zejména jeho přesná interpretace je otázkou velice problematickou a doposud částečně zanedbanou. Tato skutečnost může způsobit problémy nejenom při tvorbě koncepčních materiálů, u kterých je vyžadována součinnost NATO a ČR, ale také v př́ípadech, kdy jsou vytvářeny dokumenty strategického a operačního charakteru ve vzájemné spolupráci rezortů obrany a vnitra. K tomu, aby dopady nesprávné terminologie byly výrazně omezeny či dokonce do budoucna eliminovány, je nutné přijmout několik zásadních obecných opatření aplikovatelných víceméně obecně.

1. Urychleně dokončit proces převodu odborně zaměřené terminologie na oblast ochranu proti ZHN ze zrušené AAP-21 do AAP-6. Tímto přístupem vyplnit mezeru v současné době neexistujícího úplného a jednotného terminologického aparátu pro předmětnou oblast v NATO. Zároveň tento proces využít $\mathrm{k}$ precizaci pojmů a definic.

2. Zahájit proces zásadního přepracování názvoslovné normy NN 300101 nejenom ve vztahu $\mathrm{k}$ řešené problematice, ale průřezově.

3. Zahájit práce související se zásadním přepracováním nebo nově vydat vojenský předpis V̌̌evojsk-2-11.

4. Obnovit účast specialistů na operační a bojové použití CHV AČR společně se specialisty zabývajících se rozvojem dekontaminačních technologií na terminologických panelech NATO.

5. Důslednými překlady prováděnými výhradně ve spolupráci s vojenskými profesionály CHV AČR zabezpečit implementaci standardizačních dohod na bázi spojeneckých administrativních publikaci do vojenských předpisů a publikací řešících problematiku terminologie a názvosloví na národní úrovni.

6. Důsledně provázat alianční a národní dokumenty zabývající se problematikou terminologie do následných (aplikačních) norem. V úvodních částech těchto norem preferovat spíše metodu odkazování na originální názvoslovné dokumenty anebo vybrané pojmy definovat přesně, formou uvedení textu do uvozovek.

7. Navázat spolupráci s orgány zabývajícími se terminologií v rámci $\mathrm{CHV}$ AČR a HZS ČR.

8. Oblast terminologie považovat za primární a závažnou. Nedopustit porušování obecných zásad práce s odbornými termíny a pojmy.

9. Zahájit proces precizace dokumentů $\mathrm{v}$ době jejich přípravy vytvořením dílčích skupin zabývajících se odbornou terminologií.

10. Vyžadovat, aby odborná terminologie byla maximálně aktuální. Jako př́klad je možné uvést nutnost aktualizace Slovníku vybraných operačních pojmů z roku 2005.

11. Pokračovat v práci na rozvoji databáze pojmů v rámci projektu Česká vojenská encyklopedie, která je spravována odborem doktrín Velitelství výcviku-Vojenskou akademií ve Vyškově. Zapojením širšího spektra přispěvatelů, př́padně i odborníků ochotných přispět komentáři a dalšími 
náměty a připomínkami, se dosáhne zvýšení úrovně a kvality elektronické encyklopedie.

12. Zabezpečit jednotné chápání základního terminologického aparátu. I přesto, že je uvedeno, že ,př́i používání názvoslovné normy je třeba brát v úvahu, že v jiných oblastech vojenství, v průmyslu a v civilním životě mohou mít některé pojmy odlišný význam“, tak je nutné pracovat na sjednocení pojmů. Jejich jednotná interpretace zabezpečí nejenom stejný př́istup k plnění odborně zaměřených úkolů, ale i zvýší současnou úroveň kompatibility a interoperabilility při plnění úkolů v zahraničních i domácích operacích.

13. Prosazovat princip respektování zavedeného pojmosloví a terminologického aparátu. V př́padě, že bude převzat beze změny, pouhým odkazem na názvoslovné dokumenty jej uvést, a v případě, že jej bude pro potřeby konkrétního dokumentu specifikovat odlišně, tak jej uvést doslovně v úvodních kapitolách nově zpracovávaného dokumentu.

\section{Použitá literatura a odkazy v textu:}

[1] KOMENSKÝ, J. A. In Brezina, J. Aforizmy. 1. vyd. Košice: Východoslovenské vydavatel’stvo, 1988, 288 s. s. 205.

[2] V̌̌evojsk-2-1, Ochrana vojsk proti zbraním hromadného ničení. Praha: Ministerstvo obrany, 2009. $197 \mathrm{~s}$.

[3] V̌švojsk-2-6, Chemické zabezpečení v Armádě České republiky. 1. vyd. Praha: Ministerstvo obrany, $2008,109 \mathrm{~s}$.

[4] NN 30 0101, Chemické vojsko: Názvoslovná norma. 3. vyd. Praha: Ministerstvo obrany, 2009, $222 \mathrm{~s}$. s. 129.

[5] AAP-21, NATO Glossary of Chemical, Biological, Radiological and Nuclear Terms and Definitions, English and French, NSA, 2008.

[6] Stránky Úřadu pro obrannou standardizaci, katalogizaci a státní ověřování jakosti [online]. c 2013. [citováno 2013-04-06]. Dostupné z: <http://www.oos.army.cz/vestniky/ves0212.htm>.

[7] Sdělení ředitele Úřadu pro obrannou standardizaci, katalogizaci a státní ověřování jakosti, Věstník Ministerstva obrany, Praha: Ministerstvo obrany, 2012, částka 5, str. 150-153.

[8] ADÁMKOVÁ, Zuzana. Osobní sdělení. 4. 4. 2013.

[9] AAP-6. NATO, Glossary of Terms and Definitions, English and French, edition 2012, version 2, NSA, 2012.

[10] V̌̌evojsk-2-11, Speciální očista u vojsk. Praha: Ministerstvo národní obrany, 1985, 127 s.

[11] Vojenský výkladový slovník vybraných operačních pojmů. 1. vyd. Vyškov: Správa doktrín Ředitelství výcviku a doktrín, 2005, $361 \mathrm{~s}$.

[12] Pub-36-16-02, Zásady ochrany proti zbraním hromadného ničení v operacích NATO na taktické úrovni velení. 1. vyd. Vyškov: Odbor doktrín VeV-VA, 2012, 267 s.

[13] STANAG 2451, Spojenecká společná doktrína k ochraně proti zbraním hromadného ničení - AJP-3.8.

[14] STANAG 2521, Ochrana proti zbraním hromadného ničení v průběhu operací - ATP-3.8.1, svazek 1, v ČR zavedeno vojenským předpisem Vševojsk-2-1, Ochrana proti zbraním hromadného ničení.

[15] STANAG 2522, Specializované schopnosti ochrany proti zbraním hromadného ničení - ATP-3.8.1, svazek 2, v ČR zavedeno vojenským předpisem Vševojsk-2-14, Bojové použití chemického vojska.

[16] STANAG 2520, Standardy vzdělávání, výcviku a hodnocení v oblasti ochrany proti zbraním hromadného ničení - ATP-3.8.1, svazek 3.

[17] Stránky FAS: Federation of American Scientists [online], c 2013. [citováno 2013-04-02]. Dostupné z: $<$ http://www.fas.org/nuke/guide/usa/doctrine/army/mmcch/Decontam.htm\#OVERVIEW>.

[18] KOTINSKÝ, P. - HEJDOVÁ, J. Dekontaminace v požární ochraně. 1. vyd. Ostrava: Sdružení požárního a bezpečnostního inženýrství, 2003, 126 s. ISBN 80-86634-31-0.

[19] Sbírka interních aktư ř́zení GǨ HZS ČR, roč. 2006, částka 30. Pokyn GŘ HZS ČR ze dne 22. 12. 2006, kterým se vydává Řád chemické služby HZS ČR s odkazem na pokyn GŘ HZS ČR a náměstka MV č. 40/2001, kterým se vydává Bojový řád jednotek požární ochrany, ve znění pozdějších předpisů. 